\title{
2
}

\section{Place-Based Agricultural Development: A New Way of Thinking about an Old Idea in Northern Australia}

\author{
Jim Turnour, Kate Andrews, Allan P. Dale, Connar \\ McShane, Michelle Thompson and Bruce Prideaux
}

\section{Introduction}

The establishment of a northern food bowl has been a central theme in discussions about the development of Australia north of the Tropic of Capricorn (Australian Government, 2014; Australian Labor Party, 2013; Liberal Party of Australia, 2013). This policy drive has remained despite over a century of failed attempts to develop broad-scale cropping in the north beyond central and coastal North Queensland. This cycle of publicly expressed expectation for Northern Australia to produce food and fibre through broad-acre cropping is discussed as a 'circular conundrum' (Andrews, 2014, p. 2). This circular conundrum begins with the setting of high expectations, moves to cropping attempts, then usually to project failure, and back around to high expectations (Andrews, 2014).

This chapter argues that we must learn from these past mistakes by building on this experience to embrace new models of agriculture grounded in place-based approaches. Place-based approaches emphasise the importance of local context including sociocultural, physical and institutional factors in development (Barca, et al., 2012; Hildreth \& Bailey, 2014; Tomaney, 2010). Australia has traditionally relied on agri- 
industrial models of agriculture characterised by a focus on production and marketing of bulk commodities (Lawrence et al., 2013). Internationally, however, new models have emerged that characterise agriculture as being multifunctional, contributing not only through production but to the environmental and social sustainability of a region (Renting et al., 2009). Marsden (2003) defined a post-productivist model of agriculture that leveraged the importance of environmental sustainability and amenity and a rural development model that leveraged the links between agriculture and local communities to support development that reflected more broadly the needs for economic, environmental and social sustainability.

In an Australian context, post-productivist models of agriculture provide an opportunity to leverage Northern Australia's unique environmental values through branding for food safety, sustainability and ecosystems services. Similarly, rural development approaches to agriculture are more inclusive of the broader community. This inclusiveness is achieved, for example, through supporting diversification, value adding and creating jobs via links to regional supply chains for agricultural products. These supply chains can be centred on local communities and/or linked to new high-value markets in Asia and Southern Australia.

In Australia, the idea that agriculture is multifunctional has been resisted by policymakers because it has been used as an argument for protectionist trade policies, particularly in Europe (Cocklin et al., 2006; Renting et al., 2009). Increasingly, however, the multifunctionality of the landscape of Northern Australia is emerging in research and needs to be considered in the development of agriculture (see Bohnet $\&$ Smith, 2007; Holmes, 2006, 2012; Turnour et al., 2015).

Case study research in the Wet Tropics of North Queensland focused on developing a theoretical framework that enables consideration of agriculture's broader contributions to place-based regional development. The theoretical framework that emerged combined the traditional agriindustrial model of agriculture with emerging post-productivist and rural development models (Turnour et al., 2015). The place-based agricultural development framework developed provides a new perspective for considering agricultural development in Northern Australia based on well-contextualised regional competitive advantage. This chapter details this framework and through case studies highlights the opportunities and benefits of place-based approaches to the development of agriculture across Northern Australia. 


\section{The 'circular conundrum': Learning from Past Experiences of Cropping in Northern Australia}

Despite over a century of attempts at cropping in Northern Australia, cropping makes only a minor contribution to overall economic activity outside of central and coastal North Queensland. Approximately 88 per cent of the total agriculture production from Northern Australia is produced in Queensland, where more than 70 per cent of the region's population resides (BITRE, 2011). However, it is in these more remote regions dominated by pastoralism where high expectations are again being built around irrigated agriculture. In these regions, traditional approaches to agricultural development have produced disappointing results. In 2009, the value of irrigated agriculture production in this part of Northern Australia was worth about $\mathrm{A} \$ 160$ million, 0.8 per cent of total regional economic activity. The total irrigated area was 34,000 hectares, less than 0.03 per cent of Northern Australia. Horticulture was the highest-value crop with sandalwood (a forestry product valued at $\mathrm{A} \$ 60$ million) being of increasing importance. These cropping industries are dwarfed by the contribution of the beef industry at approximately A $\$ 1$ billion (Webster et al., 2009). Understanding the circular conundrum can help us to break the cycle of failed attempts at agricultural cropping development in Northern Australia. We can learn from the variables that lead to failed attempts and hindered learning, enabling expectations to be raised again and again.

Diverse and multiple variables have impacted on cropping attempts in Northern Australia over the last 150 years, contributing to their subsequent failure (Andrews, 2014). From the poor soils at sites of the Northern Territory sugar plantations of the 1880s to a lack of sufficient scale of production for the sugar industry on the Ord in the early 2000 s. Or the lack of a profitable rotation crop for peanuts noted in the early 1920s and still recognised as a problem for Territory peanut growers in the 2000s. From overcapitalisation and lack of managerial capacity in the Territory Rice saga of the 1950s (magpie geese scapegoated) to the lack of willingness to learn from available knowledge exhibited most egregiously by the Northern Australia Development Corporation on Willeroo Station in the 1970s (and still exhibited in less dramatic ways today). This can-do 
frontier culture was also exhibited in the heady days of Northern Development Pty Ltd at Camballin in Western Australia. These are only a few of the many examples (Andrews, 2014).

Where agriculture has been successfully developed, including in central and coastal North Queensland, it has been important to start at a manageable scale and to learn and adapt to the environment. Establishing enabling infrastructure and supply chains have been as important as overcoming the agronomic challenges. This has generally required significant government investment in irrigation infrastructure and research and development for which farmers have not had to pay a return on the sunk costs (Ash, 2014).

The relationship between these impacting variables contributes further to the complexity and vulnerability of cropping attempts. This complex socio-ecological system can be reframed and conceptualised as five assetssocial, human, natural, physical and financial. It is these five assets that are required for successful development, yet we find a lack of each as required for broad-scale cropping in most of the north. Examples include:

- Social and institutional-government legislation and policy (such as access to water resources) and access to skilled and unskilled labour

- Human-lack of agronomic knowledge and personality (such as willingness to learn from local sources and experience)

- Natural-climate (extreme temperatures, pattern of rainfall, high evaporation rates, variability and unpredictability) and soil suitability (nutrients, water holding/shedding, structure and erodibility)

- Physical/manufactured - suitable crop varieties and rotation crops and agricultural infrastructure (such as processing and storage facilities)

- Financial-high price of inputs and low and/or fluctuating price of outputs, capacity to raise or access finance.

There has been improvement in some assets over time, particularly assisting small-scale success in horticulture and pastoralism. History shows, however, that attempts to address any of these assets in isolation from the others has generally not been sufficient to ensure success. Millions of dollars of both government and private investment have been lost in efforts to do just that.

The final step in the circular conundrum is from failure back to continuing high expectations - the mystery of the persistence of the cycle. This relationship is perpetuated by 'hindered learning' (Andrews, 2014, p. 336), including the gap between 'rhetoric and reality' (Powell, 
1977 , p. 83) and 'a reprehensible aversion to learning by experience' (Bauer, 1985, p. 27). This is something Ash (2014) emphasised as being critically important where agriculture has been successfully developed in the north. Other parts of the cycle contribute to hindering learning, whether the powerful cultural drivers or the very variables that contribute to failure such as remoteness. The circular conundrum reflects settler Australia's slow journey to develop landscape literacy of the north, and our even slower journey to develop complex systems literacy including a capacity to deal with variability and complexity. It demonstrates how, to break this stubborn cycle, we need to understand the place and learn to manage complex socio-ecological systems rather than continuing with a disaggregated approach.

\section{Models of Agriculture Development and Influences on Northern Australia}

Agriculture is traditionally understood in Australia as providing food and fibre to be sold within bulk commodity markets. This approach to agriculture has been described as an agri-industrial model of production (Marsden, 2003). It underpinned the founding of the wool, beef, grain and sugar industries and the early economic development of Australia and our national identity. Agri-industrial agriculture continues to dominate Australian agricultural production and continues to influence our understanding of how agricultural development in Northern Australia should occur (Lawrence et al., 2013).

Globalisation and economic reforms that began in the 1970s, however, have changed the relative competitiveness of agri-industrial agriculture in many regions. Industry deregulation has seen a reduction in farmgate prices for commodities while costs of production have continued to rise. New business, production and transport technologies have enabled the scale of production to increase and supply chains to be consolidated. These factors have combined to see an increasing corporatisation of Australian agriculture and contributed to a decline in smaller family farms on which the agri-industrial model was founded (Productivity Commission, 2005; Turnour et al., 2015).

During the 1980s and 1990s, environmentalism also emerged as a social movement that began to call into question the sustainability of many agricultural practices. These movements began changing consumer 
preferences and farm practices. The National Landcare and Property Management Planning programs began to encourage farmers to take responsibility for the sustainable management of their natural resources and environment (Lockie \& Higgins, 2007). Today, regional natural resource management (NRM) bodies have been established across the country and significant investments are being made to improve agricultural sustainability (Dale et al., 2013). Climate change has also emerged as a major environmental risk and opportunity for Australian agriculture. Consequently, governments, industry and the community are much more aware of the risks of inappropriate agricultural development on the environment.

More recently, the re-emergence of Indigenous interests in land in Northern Australia is similarly challenging the sustainability of the agriindustrial model of agriculture. The forced removal of Indigenous people from their land and the introduction of sheep, cattle and new crops during colonial settlement significantly changed the Australian landscape (Gammage, 2011). As a result of native title, Indigenous people are now reasserting their legal rights and interests in the majority of land in Northern Australia (Hill et al., 2013; Dale, 2014). Aboriginal people must now be engaged in decision-making about any new developments. They are major landowners in their own right and there are opportunities to increase production and profitability from Indigenous-owned lands (NAILSMA, 2014). So, although the idea of agricultural development in Northern Australia continues to draw on the imagery of Australia's agriindustrial pioneering past, opportunities for agricultural development have changed significantly. Recognising and learning from this past is important if we are to break out of the circular conundrum (Andrews, 2014; Turnour, 2014).

Different visions for agricultural development in the north are emerging. The seemingly more populist approach reflected in the bipartisan Coalition and Labor policies would see significant new government investment in irrigation infrastructure and research and development (Australian Labor Party, 2013; Liberal Party of Australia, 2013). This populist vision of the north as a food bowl draws on this historical imagery rather than being based in evidence of the opportunities for agricultural development in Northern Australia. Economic analysis of large-scale irrigation developments demonstrate that they do not provide a return to the private sector without significant government investment in the water infrastructure (CSIRO, 2013; Webster et al., 2009). 
A more modest vision for agriculture development in the north was recently set out in the 2009 Northern Australia Land and Water Taskforce report. This vision, developed by industry, Indigenous and conservation interests and underpinned by a CSIRO Science Review, would rely on governments improving the investment environment for smaller-scale agricultural development through, for example, research, development and extension (RD\&E) and regulatory and tenure reform. The Australian Government White paper on developing Northern Australia similarly focused on the importance of creating the right investment environment, although large-scale irrigation development remained a central objective (Australian Government, 2015).

The diversity of the north and the competing visions and narratives of vested interests can make untangling fact from fiction difficult. As such, there is a need to maximise the contribution of established industries like the beef industry while also looking to new development opportunities. This requires an assessment of not only the physical and economic constraints and opportunities but a consideration of development proposals in the context of evolving social and environmental values and changes in the global demand pattern of food.

Considering the multiple contributions that agriculture can make to Northern Australia requires a consideration of new models of development. Two new models of agricultural development, referred to as postproductivist and rural development, have been identified internationally and were found to be operating in the Wet Tropics of Northern Australia (Turnour et al., 2015). These models provide new ways of looking at the opportunities available for agricultural development in Northern Australia. They reflect a growing recognition that agriculture can be multifunctional in its contributions to regional development (Cocklin et al., 2006; Marsden \& Farioli, 2015; Renting et al., 2009).

The post-productivist model emphasises the role of agriculture in contributing to and capitalising on the aesthetic beauty of the surrounding environment and adopting environmentally friendly farming practices (Marsden, 2003; Marsden \& Sonnino, 2008). Post-productivist agriculture is a more complex model that moves from a solely production focus to engaging not only the farmer but the wider community in NRM and environmental protection. The model recognises the increasing value being placed on agricultural lifestyles and landscape amenity reflected in rural property prices, particularly around major urban centres (Bohnet, 2008; Turnour et al., 2015). 
The rural development model makes a distinct move away from sectoror industry-focused agricultural development towards regionally focused, place-based agricultural and rural sustainability (Marsden, 2003; Marsden $\&$ Sonnino, 2008). Some strategies of a rural development approach would include place/regional branding, value adding, agri-tourism and niche marketing. The rural development model, therefore, has the capacity to leverage established agri-industrial and post-productivist models to create new markets and supply chains from Northern Australia linked to Asia, a region increasingly prepared to pay a premium for safe sustainable food (The Economist Intelligence Unit, 2013).

Each of these models provides a different approach to agricultural development. When integrated through and combined within a placebased development framework, they provide a practical tool to assist in planning and development of agriculture in Northern Australia.

\section{Place-Based Development: A New Framework for Decision-Making about Agriculture in Northern Australia}

Place-based approaches provide a new way of engaging in agricultural development that moves beyond the grand visions and narratives of northern development intrinsic to the circular conundrum. They encourage collaboration between industry, community, business and government to tackle complex social, economic and environmental problems within a defined geographic location. Properly implemented, they respect local knowledge and values while keeping communities open to outside values (Barca et al., 2012; Tomaney, 2010). This creates an environment where competing visions of agricultural development underpinned by different values are more likely to be constructively resolved. In this way, place-based approaches can provide a framework for recognising and respecting the different physical and sociocultural environments present in the regions of Northern Australia and the range of opportunities these present.

They have been adopted as a framework for NRM in Australia and form part of the Australian Government's Indigenous Advancement Strategy (Department of the Prime Minister and Cabinet, 2014). Internationally, they have been identified as providing an alternative approach to tackling 
entrenched agriculture and rural community decline as a result of globalisation and economic reforms by supporting regions to leverage their innate competitive advantages (OECD, 2006).

Recognising the strengths of place-based approaches and the emerging alternative models of agriculture provided the catalyst for the development of a new agricultural development tool in North Queensland. The placebased agricultural development framework combines the three modelsagri-industrial, post-productivist and rural development-with eight critical factors important to maximising agriculture's contribution to regional development. The three models provide different lenses to explore how agriculture can contribute to regional development. The eight factors include five assets (social capital, human capital, natural resources, infrastructure/technology and environment/amenity) that provide the foundation for agricultural development and three factors (balancing needs, strong regionalism and governance and institutions) that influence whether the different opportunities presented by the models are realised (see Figure 2.1) (Turnour et al., 2015). The frameworks' combination of assets, governance and institutional environment and models of agriculture provides a new structured way of relooking at agricultural development. This expanded vision demonstrates how agriculture can contribute to regional development building on the traditional agri-industrial model of development.
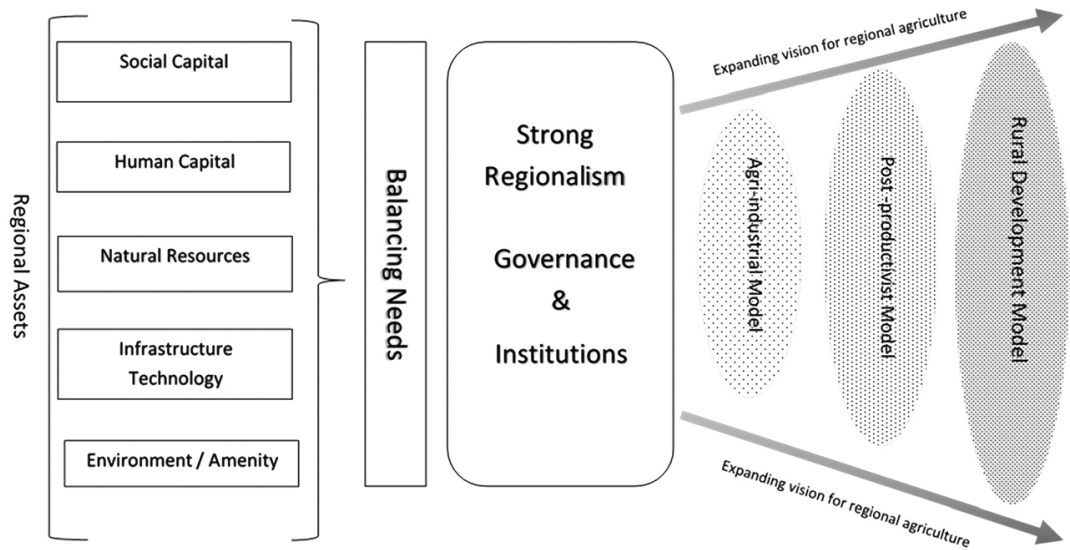

Figure 2.1: Place-based agriculture development framework.

Source: Turnour et al. (2015). 
The eight factors are elaborated on below.

Social capital is the level of connectedness and trust of people and organisations within and between local communities (Cocklin \& Alston, 2002; Onyx \& Bullen, 2000; Woodhouse, 2006). Social capital reflects an ability to work together in a cooperative and coordinated way to tackle problems. It is important to have a cohesive approach to development within a region (bonding social capital) and strong links beyond the region (bridging social capital).

Human capital is important as it is individual farmers, businesses and industry leaders who must be entrepreneurial and take the risks to identify new markets and develop new enterprises and supply chains. This requires new knowledge and skills to be developed by individuals and businesses and provides opportunities for new and younger farmers to enter into agriculture.

Natural resources including soils, water, topography and climate underpin the type of agriculture that is possible within a region.

Infrastructure/technology are critically important as combining infrastructure and technology (transport, information and communication technologies and energy) with security of access to natural resources (land and water) can change the relative competitiveness of agriculture within a region.

Environment/amenity can underpin new industries and regional supply chains based on food safety and sustainability and regional tourism. They can also underpin increasing land values as rural amenity and lifestyle are increasingly sought-after commodities.

Balancing needs emphasises that different agriculture businesses balance a range of needs according to their varying economic, environmental and social values. Businesses may be focused on different models or have income streams outside of agriculture. The capacity within a region to recognise and enable agricultural businesses to manage what can be competing needs can influence a business's ability to engage in development.

Strong regionalism reflects the need for industry and regional self-reliance post-deregulation. It also stresses the need for regions to speak with a strategic and coordinated voice and for development to be controlled and driven regionally. 
Effective governance and institutions are critical to creating the right environment for expanding agriculture's contribution within a region. This includes the values and norms reflected through community and industry-based organisations and governments' and corporations' policies and regulations that mediate agricultural production and associated markets and supply chains (Turnour et al., 2015).

\section{Applying Place-Based Agricultural Development in Northern Australia}

Applying the place-based agricultural development framework to Northern Australia would enable a wider range of agricultural development opportunities to be considered and supported. As the framework details, development is dependent on a range of factors (see Figure 2.1) and there are unique challenges to agricultural development in Northern Australia that need to be considered. Some of these are fixed assets, such as natural resources and environment/amenity, while other factors are evolving and changing, such as human and social capital and infrastructure/technology. These changes are influenced by the governance and institutional environment that regulate land use, export opportunities and a range of operational matters such as occupational health and safety.

Government policy, not always in obvious ways, plays an important role in establishing the governance and institutional environment that has shaped agricultural development. Trade, immigration and Indigenous policies have been important, as have economic investments in infrastructure and RD\&E (Turnour, 2014). Breaking out of the circular conundrum, therefore, particularly involves understanding and creating a governance and institutional environment that can support a range of different models of agricultural development. As these cases demonstrate, there are new and emerging opportunities for agriculture in the north.

Growing food and fibre is still central to agriculture; too often, however, governments overlook investments in rural development that can produce additional returns and employment from agriculture. The environment and a rural lifestyle similarly provide opportunities for additional returns for agriculture that should not be overlooked. The following two case studies are examples of post-productivist and rural development approaches to agriculture in Northern Australia. They emerged out of 
research in the Wet Tropics of North Queensland including focus groups, interviews and literature reviews (Turnour et al., 2015). They are examples of how agri-industrial agriculture is being built on to generate multiple contributions to regional development. They represent examples of how wider views of agriculture are emerging in a place-based context across Northern Australia.

\section{Ecosystem Services and Carbon in Northern Australia}

If we are to create a place-oriented multifunctional approach to agriculture inclusive of a functioning ecosystem services economy, a simple and understandable national stewardship-oriented policy framework needs to emerge. A new national framework could establish in-principle agreement on the need for society to pay for those ecosystem services delivered by land managers over and above their current duty of care responsibilities. The Australian Government would also need to, through the development of cohesive national partnerships with key stakeholder sectors, secure an appropriate policy and delivery framework for managing these ecosystem service payments (see, for example, Van Oosterzee et al., 2010). Without a cohesive policy framework of this kind, urban and rural Australia will struggle to reconcile their cultural divide. This is the current situation as governments continue to take a simplistic approach to regulating away the economic opportunities of land managers to deliver the ecosystem services desired and needed by those living in Australia's cities (Dale, 2014).

There are already some emerging market-based approaches within a broader policy-based stewardship framework that could fund a range of ecosystems services (e.g. carbon trading). In the Wet Tropics region of North Queensland, for example, from 2005 to 2010, Terrain NRM (the regional NRM body for Queensland's Wet Tropics) partnered with a private sector entity (Biocarbon) to work towards establishing the Wet Tropics region as an international supplier of quality ecosystems service credits (see Van Oosterzee et al., 2012, for details). The alliance sought to pool (or aggregate) a range of carbon products arising from improved land use activities that delivered on the region's NRM plan. In addition to carbon sequestration or abatement, these activities would deliver other measurable biodiversity and community benefits. At the time, market brokers heavily involved in the world's emerging ecosystem 
services markets were buoyant that the region's high forest growth rates, high endemic biodiversity, localised scientific capacity and institutional stability would make the region's potential biosequestration products a jewel in the crown among what the world has to offer.

It is also important to note that the northern savanna also similarly provides opportunities for such emerging markets. Recently, the Tipperary Group of Stations were issued over 26,000 credits in 2013 for early season burning under the savanna burning carbon farming methodology (Brann, 2012). Getting the policy and institutional environment right is critical to securing these opportunities. A cohesive policy response to the development of ecosystem service markets, however, should never just continue to be about reducing carbon emissions alone. Indeed, it must, in parallel, encourage global efforts towards the protection and enhancement of biodiversity, cultural diversity and food security (see Dale, 2014, pp. 113-122). This means:

- setting up a wider policy framework for combining good landscapescale regulation with balanced efforts to enhance landholder contributions to environmental or land stewardship

- establishing trading systems that enable society to offset the impact of its consumption on biodiversity, agricultural sustainability and water quality.

We need both a wider policy framework that embeds a place-oriented, integrated approach to landscape-scale management and a clear national framework for the development of ecosystems services trading products and services delivered in alignment with this system.

\section{Regional Food Network Tropical North Queensland}

The Regional Food Network (RFN) is an example of how farmers building on established agri-industrial industries have adopted what could be described as a rural development approach to remain viable. Reconnecting communities with regional or local food is a key component to implementing place-based agricultural development (Kneafsey, 2010). The network is made up of mostly family-owned businesses that have set themselves apart through value adding, niche marketing and diversification. The network has developed its own brand, 'Taste Paradise' 
making the most of tropical North Queensland's clean green image and its tourism industry to generate additional value for farm-based products (see www.tasteparadise.com.au).

Established in 2011, the success of the RFN can be attributed to leveraging the region's competitive advantages. It capitalises on the region's assets, facilitating a greater connectivity between existing businesses and producers, addressing one of the major challenges of successful development at a regional level (Iyer et al., 2005; Marsden \& Smith, 2005; Sharp \& Smith, 2003). The RFN facilitated this greater connectivity in a number of ways. It capitalised on tourists' behaviours through promoting the natural aesthetics of the region and existing value-added farm businesses. In turn, community businesses and organisations have supported the RFN by promoting product origin. Further, the network also built a relationship of trust with consumers through brand development, whereby members of the supply chain need to become accredited. Accreditation assures the consumer that the product is grown, sourced, distributed and sold locally. In doing so, the network demonstrates an understanding of the need to work with other regional organisations and businesses outside of agriculture to increase the demand for regional or local produce and products and the importance of understanding consumer preferences.

These short regional supply chains can be applied to multiple regions throughout the north and with appropriate support built on to link into Asian markets. Using the rural development model as a framework and following the example of the RFN, the first step would be to audit the regions for existing businesses, facilities and resources to identify opportunities for development. The second step would be to encourage the involvement of local supply chain stakeholders, from farmers to consumers. Many people are reluctant to engage in new strategies or markets due to time and financial concerns, or are simply unaware of the supply chain and how to access it or have a lack of trust in the system (Marsden \& Smith, 2005; Maxey, 2006). Barriers can be overcome, as demonstrated by the RFN, by effectively communicating information about the network's role, existing members and accreditation process to consumers and potential members of the network. Therefore, strong regional governance, including transparency in policy, clear communication to all stakeholders and demonstrating an understanding of stakeholder needs or barriers to engagement, is essential for successful development at a regional level (Michelini, 2013). 
As is evident by a place-based approach, the types of systems put in place will inevitably vary from region to region. However, fundamental to success of a regional supply chain is a whole-of-system approach, whereby government and industry policies both encourage and facilitate farmer adoption of alternative supply chains and niche markets. Without this supportive framework, engaging farmers in alternative, local supply chains that build on established agri-industrial industries can be difficult.

\section{Conclusion}

If we are to break out of the circular conundrum we need to learn from the past and take a new look at the ways that agriculture can contribute to regional development in Northern Australia. There are real opportunities to build on existing agri-industrial industries in Northern Australia, as these case studies have demonstrated. For too long, the main focus has simply been on new large-scale irrigated agricultural projects as the way to develop the north. History demonstrates, however, that starting small while developing the necessary human and physical assets and supply chains has been more successful (Andrews, 2014; Ash, 2014).

The place-based agriculture development framework provides a tool for policymakers, industries and communities to explore the different contributions that agriculture can make. Encouraging new narratives and visions for northern agriculture that are grounded not in old myths but in a deeper understanding of the physical, environmental and sociocultural assets of a region. When people are actively engaged and supported through place-based policies and institutional arrangements, they have the capacity to produce economic, environmental and social benefits that can uniquely leverage the assets and opportunities intrinsic to a place.

\section{Acknowledgements}

The authors would like to acknowledge the Australian Government's Rural Industries Research and Development Corporation for funding the research that underpinned the development of the place-based agricultural development framework detailed in this chapter. 


\section{References}

Andrews, K. (2014). 'The Circular Conundrum': 150 years of cropping and complexity in north-west Australia (unpublished doctoral thesis). The Australian National University, Canberra, ACT.

Ash, A. J. (2014). Factors driving the viability of major cropping investments in northern Australia - a historical analysis. CSIRO.

Australian Government. (2014). Green paper on developing Northern Australia. Canberra, ACT: Department of the Prime Minister and Cabinet. Retrieved from www.regional.gov.au/regional/northernaustralia/

Australian Government. (2015). Our north, our future: White paper on developing Northern Australia. Retrieved from www.industry.gov.au/data-and-publications/ our-north-our-future-white-paper-on-developing-northern-australia

Australian Labor Party. (2013). Growing the north: A plan for Northern Australia. Retrieved from d3n8a8pro7vhmx.cloudfront.net/australianlaborparty/pages/ 935/attachments/original/1376536954/Fact_Sheet_-_Growing_the_North. pdf? 1376536954

Barca, F., McCann, P. \& Rodríguez-Pose, A. (2012). The case for regional development intervention: Place-based versus place-neutral approaches, Journal of Regional Science, 52(1), 134-152. doi.org/10.1111/j.1467-9787. 2011.00756.x

Bauer, F. H. (1985). A brief history of agriculture in north-west Australia. In R. Muchow (Ed.), Agro-research for the semi-arid tropics: North-West Australia (pp. 12-31). Brisbane, Qld: University of Queensland Press.

Bohnet, I. (2008). Assessing retrospective and prospective landscape change through the development of social profiles of landholders: A tool for improving land use planning and policy formulation. Landscape and Urban Planning, 88(1), 1-11. doi.org/10.1016/j.landurbplan.2008.07.002

Bohnet, I. \& Smith, D. M. (2007). Planning future landscapes in the Wet Tropics of Australia: A social-ecological framework. Landscape and Urban Planning, 80(1), 137-152. doi.org/10.1016/j.landurbplan.2006.07.001

Brann, M. (2012, 20 September). Cattle giant to cash in carbon credits. $A B C$ Rural. Retrieved from www.abc.net.au/news/2013-09-20/tipperarycarbon-credits/4970806 
Bureau of Infrastructure, Transport and Regional Economics (BITRE). (2011). Northern Australia statistical compendium 2011 update. Canberra, ACT: BITRE. Retrieved from www.bitre.gov.au/sites/default/files/stats_014.pdf

Cocklin, C. \& Alston, M. (Eds). (2002). Community sustainability in rural Australia: A question of capital? Wagga Wagga, NSW: Academy of the Social Sciences in Australia.

Cocklin, C., Dibden, J. \& Mautner, N. (2006). From market to multifunctionality? Land stewardship in Australia. Geographical Journal, 172(3), 197-205. doi.org/ 10.1111/j.1475-4959.2006.00206.x

Commonwealth Scientific and Industrial Research Organisation (CSIRO). (2013). Agricultural resource assessment for the Gilbert Catchment. An overview report to the Australian Government from the CSIRO Flinders and Gilbert agricultural resource assessment, part of the north Queensland irrigated agriculture strategy. Brisbane, Qld: CSIRO.

Dale, A. P. (2014). Beyond the north-south culture wars: Reconciling northern Australia's past with its future (SpringerBriefs in Geography Series). The Netherlands: Springer.

Dale, A. P., McKee, J., Vella, K. \& Potts, R. (2013). Carbon, biodiversity and regional natural resource planning: Towards high impact next generation plans. Australian Planner, 50(4), 328-339. doi.org/10.1080/07293682.2013.764908

Department of the Prime Minister and Cabinet. (2014). Indigenous affairs budget 2014-15, Indigenous Advancement Strategy. Canberra, ACT: Commonwealth of Australia.

The Economist Intelligence Unit. (2013). A healthy future for all? Improving food quality for Asia. Retrieved from perspectives.eiu.com/sites/default/files/A\%20 Healthy\%20Future\%20For\%20All_main_Oct16_V3.pdf

Gammage, B. (2011). The biggest estate on earth: How Aborigines made Australia. Sydney, NSW: Allen \& Unwin.

Hildreth, P. \& Bailey, D. (2014). Place-based economic development strategy in England: Filling the missing space. Local Economy, 29(4-5), 363-377.

Hill, R., Pert, P. L., Davies, J., Robinson, C. J., Walsh, F. \& Falco-Mammone, F. (2013). Indigenous land management in Australia: Extent, scope, diversity, barriers and success factors. Cairns, Qld: CSIRO Ecosystems Science.

Holmes, J. (2006). Impulses towards a multifunctional transition in rural Australia: Gaps in the research agenda. Journal of Rural Studies, 22(2), 142-160. 
Holmes, J. (2012). Cape York Peninsula, Australia: A frontier region undergoing a multifunctional transition with Indigenous engagement. Journal of Rural Studies, 28(3), 252-265.

Iyer, S., Kitson, M. \& Toh, B. (2005). Social capital, economic growth and regional development. Regional Studies, 39(8), 1015-1040.

Kneafsey, M. (2010). The region in food-important or irrelevant? Cambridge Journal of Regions, Economy and Society, 3(2), 177-190.

Lawrence, G., Richards, C. \& Lyons, K. (2013). Food security in Australia in an era of neoliberalism, productivism and climate change. Journal of Rural Studies, 29, 30-39.

Liberal Party of Australia. (2013). The Coalition's 2030 vision for developing Northern Australia. Retrieved from parlinfo.aph.gov.au/parlInfo/search/display/display. w3p;query=Id\%3A\%22library\%2Fpartypol\%2F2550511\%22;src1=sm 1

Lockie, S. \& Higgins, V. (2007). Roll-out neoliberalism and hybrid practices of regulation in Australian agri-environmental governance. Journal of Rural Studies, 23(1), 1-11. doi.org/10.1016/j.jrurstud.2006.09.011

Marsden, T. (2003). The condition of rural sustainability. Assen, The Netherlands: Uitgeverij Van Gorcum.

Marsden, T. \& Farioli, F. (2015). Natural powers: From the bio-economy to the eco-economy and sustainable place-making. Sustainability Science, 10(2), $331-344$.

Marsden, T. \& Smith, E. (2005). Ecological entrepreneurship: sustainable development in local communities through quality food production and local branding. Geoforum, 36(4), 440-451.

Marsden, T. \& Sonnino, R. (2008). Rural development and the regional state: Denying multifunctional agriculture in the UK. Journal of Rural Studies, 24, 422-431. doi.org/10.1016/j.jrurstud.2008.04.001

Maxey, L. (2006). Can we sustain sustainable agriculture? Learning from smallscale producer-suppliers in Canada and the UK. Geographical Journal, 172(3), 230-244. doi.org/10.1111/j.1475-4959.2006.00211.x

Michelini, J. J. (2013). Small farmers and social capital in development projects: Lessons from failures in Argentina's rural periphery. Journal of Rural Studies, 30, 99-109. doi.org/10.1016/j.jrurstud.2013.01.001 
North Australian Indigenous Land and Sea Management Alliance (NAILSMA). (2014). An Indigenous prospectus for northern development: Effective engagement, resilient communities, secure futures. Submission to Parliament of Australia: Joint Committee on Northern Australia, Canberra.

Northern Australia Land and Water Taskforce. (2009, December). Sustainable development in Northern Australia, A report to Government from the Northern Australia Land and Water Taskforce. Canberra, ACT: Department of Infrastructure, Transport, Regional Development and Local Government.

Onyx, J. \& Bullen, P. (2000). Measuring social capital in five communities. The Journal of Applied Behavioral Science, 36(1), 23-42. doi.org/10.1177/ 0021886300361002

Organisation for Economic Co-operation and Development (OECD). (2006). The new rural paradigm: Policies and governance. Paris, France: OECD.

Powell, J. M. (1977). Mirrors of the New World-Images and Image-makers in the Settlement Process. Folkestone, England: Dawson and Archon Books.

Productivity Commission. (2005). Trends in Australian agriculture (Research paper). Canberra, ACT: Productivity Commission.

Renting, H., Rossing, W. A. H., Groot, J. C. J., Van der Ploeg, J. D., Laurent, C., Perraud, D., ... Van Ittersum, M. K. (2009). Exploring multifunctional agriculture. A review of conceptual approaches and prospects for an integrative transitional framework. Journal of Environmental Management, 90, S112-S123.

Sharp, J. S. \& Smith, M. B. (2003). Social capital and farming at the rural-urban interface: The importance of nonfarmer and farmer relations. Agricultural Systems, 76(3), 913-927.

Tomaney, J. (2010, November). Place-based approaches to regional development: Global trends and Australian implications. Sydney, NSW: Australian Business Foundation.

Turnour, J. (2014). Northern Australia agriculture policy: Opportunities and risks. In The Regional Australia Institute, Green paper on developing Northern Australia: A joint submission to the Northern Australia taskforce (pp. 63-70). Canberra, ACT: The Regional Australia Institute.

Turnour, J., Dale, A., McShane, C., Thompson, M., Prideaux, B. \& Atkinson, M. (2015). A place-based agriculture development framework (Project report). Canberra, ACT: Rural Industries Research and Development Corporation. 
Van Oosterzee, P., Preece, N. \& Dale, A. (2010). Catching the baby: Accounting for biodiversity and the ecosystem sector in emissions trading. Conservation Letters, 3(2), 1-8. doi.org/10.1111/j.1755-263X.2009.00090.x

Van Oosterzee, P., Preece, N. \& Dale, A. (2012). An Australian landscape-based approach: AFOLU mitigation for smallholders. In E. Wollenberg, M.-L. Tapio-Bistrom, M. Grieg-Gran \& A. Nihart (Eds), Climate change mitigation and agriculture (pp. 193-202). Abingdon, England: Routledge.

Webster, T., Morison, J., Abel, N., Clark, N., Rippin, L., Herr, A., ... Wilson, P. (2009). Irrigated agriculture: Development opportunities and implications for Northern Australia. Canberra, ACT: CSIRO.

Woodhouse, A. (2006). Social capital and economic development in regional Australia: A case study. Journal of Rural Studies, 22(1), 83-94. doi.org/ 10.1016/j.jrurstud.2005.07.003 
This text is taken from Leading from the North: Rethinking Northern Australia Development, edited by Ruth Wallace, Sharon Harwood, Rolf Gerritsen, Bruce Prideaux, Tom Brewer, Linda Rosenman and Allan Dale, published 2021 by ANU Press, The Australian National University, Canberra, Australia. 